\title{
Hyperbaric oxygen therapy in the management of two cases of hydrogen sulfide toxicity from liquid manure
}

\author{
Richard Belley, MD, CFPC; ${ }^{*}$ Nicolas Bernard, MD; ${ }^{*}$ Mario Côté, MD; ${ }^{*}$ Francois Paquet, MD, CSPQ; \\ Julien Poitras, MD, CSPQ ${ }^{\dagger}$
}

\begin{abstract}
Hydrogen sulfide is a potent lethal gas. Supportive care, nitrite therapy and hyperbaric oxygen are the treatment modalities reported in the literature in cases of hydrogen sulfide exposure. We describe an industrial exposure in which 6 workers inhaled high concentrations of hydrogen sulfide when they entered a closed spreader tank partially filled with liquid swine manure. Five of the 6 lost consciousness, and 2 were agitated and poorly responsive on arrival to the emergency department despite having already received high-flow oxygen for nearly 1 hour. These 2 patients received nitrite therapy followed by orotracheal intubation and hyperbaric oxygen. All patients were discharged home without sequelae after short stays in hospital. The emergency management of hydrogen sulfide exposure is briefly reviewed.
\end{abstract}

Key words: hyperbaric oxygen therapy; hydrogen sulfide; liquid swine manure; nitrite therapy

\begin{abstract}
RÉSUMÉ
L'hydrogène sulfuré est un gaz létal puissant. Dans les cas d'exposition à ce gaz, les modalités de traitement relevées dans la littérature sont les soins de soutien, la thérapie à l'oxyde nitrique et l'oxygénothérapie hyperbare. Une exposition industrielle où six travailleurs inhalèrent de fortes concentrations $d$ 'hydrogène sulfuré après avoir pénétré dans un réservoir d'épandeur fermé et partiellement rempli de lisier de porc liquide est présentée. Cinq des six travailleurs perdirent conscience et deux étaient agités et présentaient une réactivité médiocre à leur arrivée au département d'urgence, bien qu'ils aient reçu de l'oxygène à haut débit pendant presque une heure. Ces deux patients furent soumis à une thérapie à l'oxyde nitrique suivie d'une intubation orotrachéale et d'une oxygénothérapie hyperbare. Tous les patients reçurent leur congé sans séquelles après une courte hospitalisation. La prise en charge à l'urgence de l'exposition à l'hydrogène sulfuré est brièvement passée en revue.
\end{abstract}

\section{Introduction}

Hydrogen sulfide is a colourless gas that has been recognized as an occupational hazard for at least 2 centuries. ${ }^{1}$ It has been referred to as the "knock down gas" because inhalation of high concentrations can cause immediate loss of consciousness and death. Hydrogen sulfide is found in significant concentration in livestock wastes kept in large tanks in the farming industry. Up to $5 \%$ of patients with hydrogen sulfide intoxication die at the scene. Those who survive to reach the emergency department (ED) typically present with coma, neurological symptoms and respiratory

*Clinical Professor, and †Associate Professor, Hyperbaric Medicine Service, Emergency Department, Hôtel Dieu de Lévis, Centre Hospitalier Affilié à I'Université Laval, Université Laval, Québec, Que.

Received: Jan. 11, 2005; final submission: Apr. 19, 2005; accepted: May 14, 2005

This article has been peer reviewed.

Can J Emerg Med 2005;7(4):257-61 
distress from pulmonary edema. ${ }^{2}$ Long-term neurological and neuropsychiatric sequela have been reported, as well as delayed neuropsychiatric symptoms up to 5 years postexposure. ${ }^{3,4}$ Supportive care, nitrite administration and hyperbaric oxygen therapy are the treatment options reported in the literature, although hyperbaric oxygen remains controversial because of the lack of good clinical studies.

\section{Case report}

Six workers were exposed to gas from liquid swine manure stocked in a spreader tank. Without using any protective or respiratory apparatus, they attempted to repair a defective valve inside the tank, which contained 4 to 5 inches of liquid swine manure. Patient 1, a 48-year-old male, was the first to enter the tank; he rapidly lost consciousness. Patient 2, a 16-year-old male, entered the tank in an attempt to rescue Patient 1 and rapidly lost consciousness as well. Their length of stay in the tank is estimated to be 30 to 40 minutes. Paramedics reported that Patient 1 had seizures lasting 2 to 3 minutes as he was being extricated from the tank. All patients were decontaminated on site, received $100 \%$ oxygen by non-rebreather mask and were transferred to our ED. The interval from rescue to ED arrival was approximately 50 minutes.

Investigators subsequently failed to detect hydrogen sulfide in the tank on site; however, their measurements were made using a probeless 4-gas analyzer held over the top opening after the tank had been vented (the gas analyzer was later found to be defective). A simulation reproducing the circumstances of the accident suggested that the likely gas concentrations in the tank were as follows: 440 parts per million (ppm) of hydrogen sulfide, $13600 \mathrm{ppm}$ of carbon dioxide, more than $50 \mathrm{ppm}$ ammonia, $3300 \mathrm{ppm}$ of methane, $1.5 \mathrm{ppm}$ of carbon monoxide and $20.2 \%$ oxygen. ${ }^{5,6}$

\section{Patient 1}

On arrival in the ED, the patient was anxious and agitated with abnormal vital signs and lab values (Table 1). Inhaled amyl nitrite $0.3 \mathrm{mg}$ was administered within 10 minutes of the patient's arrival, followed by intravenous (IV) sodium nitrite, $300 \mathrm{mg}$. He became poorly responsive, and his vital signs deteriorated; therefore he was intubated using a rapid sequence technique. His ECG and cerebral computed tomography (CT) were normal, and the chest x-ray demonstrated an alveolar infiltrate in the right upper lobe. Intravenous methylprednisolone $125 \mathrm{mg}$ was administered, and he was moved to our Perry Sigma Dualplace Hyperbaric System chamber (Perry Baromedical Corporation, Riviera
Beach, Fla.). Three hyperbaric oxygen (HBO) treatments were administered at 6,12 and 22 hours post arrival. Each treatment consisted of $100 \%$ oxygen for 90 minutes. Treatments were conducted under sedation and neuromuscular blockade, the first at 2.8 absolute atmospheres and subsequent treatments at 2.4 absolute atmospheres.

The chest x-ray normalized within 24 hours, and the patient was extubated at 72 hours. He was discharged from hospital 4 days post-extubation with residual short-term retrograde amnesia; however, the patient and his relatives felt his memory function had returned to normal. At 2month follow-up, he felt well but described headaches and dizziness that persisted 48 hours after hospital discharge, as well as tiredness and lassitude that lasted a week. He still complained of short-term memory problems that did not affect his day-to-day life. His Mini-Mental Status Exam score was 29/30. No other abnormalities were noted in the history and physical exam. Full neuropsychiatric testing was not done.

\section{Patient 2}

In the field, paramedics documented significant hypotension $(80 / 60 \mathrm{~mm} \mathrm{Hg})$, but this resolved prior to ED arrival (Table 1). Upon arrival, inhaled amyl nitrite $0.3 \mathrm{mg}$ was administered, followed by sodium nitrite $300 \mathrm{mg}$ IV. The patient became less reponsive and lost airway protection, so was intubated using a rapid sequence technique. Results of an ECG and cerebral CT were normal. The chest CT demonstrated severe diffuse alveolar infiltrates of the right lung and minor alveolar infiltrates of the left lung. Methylprednisolone $125 \mathrm{mg} \mathrm{IV}$, clindamycin $900 \mathrm{mg} \mathrm{IV}$, and ciprofloxacin $400 \mathrm{mg}$ IV were given, and HBO therapy was administered at 4, 17 and 25 hours post-arrival, following the same protocol described for Patient 1. This patient's troponin I level was slightly increased at 5 hours post admission but normalized within 48 hours and there were no ECG changes during the hospital stay. The chest $\mathrm{x}$-ray normalized within 48 hours, the patient was extubated prior to the last hyperbaric treatment, and he was discharged home 2 days post exposure.

At 2-month follow up, the patient felt well and had resumed school without apparent cognitive sequela, although he stated he had been tired, with headaches and concentration problems that prohibited him from attending school for at least 2 weeks following the event. Follow-up physical exam was normal, as were chest x-ray and respiratory function tests, and he scored 30/30 on the Mini-Mental Status Exam. Full neuropsychiatric testing was not done.

Patients 3 to 6 had less severe exposures, although 3 of them also lost consciousness in the tank. All were alert 
with normal vital signs on ED arrival; all received 100\% oxygen by non-rebreather mask for 4 to 6 hours; and all were discharged home.

\section{Discussion}

Fermentation of liquid manure produces about 150 different gases, including hydrogen sulphide, carbon monoxide, methane and ammonia. ${ }^{7}$ Hydrogen sulfide poses the greatest potential hazard because it is toxic and causes loss of consciousness at much lower concentrations than the oth- ers. ${ }^{7}$ Carbon monoxide and methane can also cause loss of consciousness but, based on their low concentrations during the incident simulation, we believe they did not contribute significantly to the morbidity described in these case reports. ${ }^{5}$ Hypoxemia is another possible cause of coma, but is less likely since measured $\mathrm{PO}_{2}$ levels were normal during the simulation. Ammonia has a powerful irritant effect that discourages patients from staying in contact with it long enough to lose consciousness. At levels of 700-1000 ppm, hydrogen sulfide causes coma, convulsions and, potentially, cardiorespiratory arrest. ${ }^{89}$ Our simu-

\begin{tabular}{|c|c|c|c|}
\hline Variable & $\begin{array}{l}\text { Normal } \\
\text { values }\end{array}$ & Patient 1 & Patient 2 \\
\hline \multicolumn{4}{|l|}{ Vital signs* } \\
\hline \multicolumn{2}{|l|}{ Blood pressure, mm HG } & $162 / 65$ & $104 / 70$ \\
\hline \multicolumn{2}{|l|}{ Temperature (rectal), ${ }^{\circ} \mathrm{C}$} & 37.5 & 37.8 \\
\hline \multicolumn{2}{|l|}{ Respiration rate, breaths/min } & 24 & 24 \\
\hline \multicolumn{2}{|l|}{ Heart rate, beats/min } & 110 & 104 \\
\hline \multicolumn{2}{|l|}{ Oxygen saturation, \% } & $100^{\dagger}$ & $93^{\dagger}$ \\
\hline \multicolumn{4}{|l|}{ Lab results } \\
\hline \multicolumn{4}{|l|}{ Arterial blood gas ${ }^{\ddagger}$} \\
\hline $\mathrm{pH}$ & $7.35-7.45$ & 7.37 & 7.27 \\
\hline $\mathrm{PO}_{2}, \mathrm{~mm} \mathrm{HG}$ & $70-110$ & 175 & 114 \\
\hline $\mathrm{PCO}_{2}, \mathrm{~mm} \mathrm{Hg}$ & $35-48$ & 40 & 45 \\
\hline $\mathrm{HCO}_{3}, \mathrm{mmol} / \mathrm{L}$ & $22-26$ & 22 & 20 \\
\hline Blood glucose, $\mathrm{mmol} / \mathrm{L}$ & $3.6-11.0$ & 11.0 & 11.4 \\
\hline $\mathrm{CPK}, \mu \mathrm{mol} / \mathrm{L}$ & 0-195 & 134 & 355 \\
\hline Troponine I, ${ }^{\S} \mu \mathrm{g} / \mathrm{L}$ & $<0.5$ & 0.02 & 1.52 \\
\hline BUN, $\mathrm{mmol} / \mathrm{L}$ & $2.5-8.5$ & 7.0 & 11.4 \\
\hline Blood creatinine, $\mu \mathrm{mol} / \mathrm{L}$ & $57-108$ & 111 & 93 \\
\hline Sodium, mmol/L & $135-147$ & 143 & 141 \\
\hline Potassium, mmol/L & $3.5-5.3$ & 3.6 & 3.3 \\
\hline Chloride, $\mathrm{mmol} / \mathrm{L}$ & 98-109 & 102 & 100 \\
\hline AST, $\mu / \mathrm{L}$ & $0-40$ & $n / a$ & 63 \\
\hline $\mathrm{ALT}, \mu / \mathrm{L}$ & $0-45$ & $n / a$ & 54 \\
\hline Carboxyhemoglobin, \% & $<3$ & 0.4 & 0.3 \\
\hline Lactate, ${ }^{\S} \mathrm{mmol} / \mathrm{L}$ & $0.6-2.4$ & 2.8 & 1.1 \\
\hline Sulfhemoglobin & $\mathrm{n} / \mathrm{a}$ & $\mathrm{n} / \mathrm{a}$ & $\mathrm{n} / \mathrm{a}$ \\
\hline Methemoglobin, $\%$ & $0-3$ & 0.9 & 1.5 \\
\hline \multicolumn{4}{|c|}{$\begin{array}{l}\mathrm{ALT}=\text { alanine aminotransferase }(\mathrm{SGPT}) ; \mathrm{AST}=\text { aspartate aminotransferase }(\mathrm{SGOT}) ; \\
\mathrm{BUN}=\text { blood urea nitrogen; } \mathrm{CPK}=\text { creatine phosphokinase; } \mathrm{HCO}_{3}=\text { bicarbonate; } \\
\mathrm{PCO}_{2}=\text { partial pressure of carbon dioxide; } \mathrm{pH}=\text { hydrogen ion concentration; } \mathrm{PO}_{2^{\prime}}=\text { partial } \\
\text { pressure of oxygen } \\
* \text { Vital signs taken on arrival in the emergency department }(\mathrm{ED}) . \\
\text { tOxygen saturation with } 100 \% \text { inspired oxygen with non-rebreather mask. } \\
\text { ₹Arterial blood gas done after intubation with } 100 \% \text { inspired oxygen with an } \mathrm{ABL} 730 \\
\text { (Radiometer Copenhagen, Denmark). } \\
\text { SLactate, troponine I and methemoglobinemia taken } 5 \text { hours post arrival in the ED. Other lab } \\
\text { values at arrival in the ED. }\end{array}$} \\
\hline
\end{tabular}


lation suggested levels of $\sim 440 \mathrm{ppm}$, but estimates ranged from 77 to $2200 \mathrm{ppm}$ depending on a number of factors. ${ }^{5}$ In addition, actual $\mathrm{H}_{2} \mathrm{~S}$ concentrations in the spreader tank could have reached higher levels due to manure agitation by the workers themselves. ${ }^{10}$

\section{Pathophysiology}

Hydrogen sulfide is absorbed through the lungs and causes toxic effects by binding cytochrome oxidase aa3, inhibiting oxidative phosphorylation and inducing cellular anoxia. It is metabolized by oxidation, methylation and metalloprotein reactions, and it is rapidly detoxified to sulfate and thiosulfate by an oxyhaemoglobin-catalyzed reaction. ${ }^{9}$

Organs with exposed membrane surface and those with high oxygen demands - notably the brain, lungs and heart - are most susceptible to injury. ${ }^{1}$ Brain damage from hydrogen sulfide poisoning is secondary to cerebral edema and ischemic injury, mostly to the brain stem, basal ganglia, hippocampus and vestibular apparatus. ${ }^{3}$ Lung injury results from alteration of pulmonary surfactant, ${ }^{11}$ impaired bacterial defences, ${ }^{12}$ and mucosal edema. Both patients described in this report demonstrated alveolar infiltrates initially thought to be infectious or inflammatory, but their rapid resolution suggested an inflammatory origin; hence the final diagnosis of inhalation alveolitis. Patient 2 had a borderline troponin elevation without ECG changes, suggesting minimal myocardial toxicity. Myocarditis has previously been documented as the cause of death in a postmortem examination of a patient who inhaled hydrogen sulfide..$^{13}$

\section{Treatment}

After rapid extrication from the site of hydrogen sulfide exposure, therapeutic goals are to inhibit sulfide binding to cytochrome oxidase and to promote sulfide detoxification. Amyl nitrite and sodium nitrite induce methemoglobin, which combines with hydrogen sulfide to form sulfmethemoglobin, a less toxic substance that competes with and displaces $\mathrm{H}_{2} \mathrm{~S}$ from its cytochrome oxidase binding sites. ${ }^{14}$ These postulated effects - rapid detoxification of hydrogen sulfide in the blood and reactivation of cytochrome oxidase - are potentially life-saving; therefore nitrite therapy should be initiated as soon as possible. ${ }^{1,14-17}$ Adverse effects of nitrite therapy include hypotension, vomiting, headache and interference with hemoglobin-oxygen dissociation due to excessive methemoglobin formation. Both patients described here deteriorated after nitrite administration, illustrating the potential hazards of this widely recommended therapy.
Oxygen competes with hydrogen sulfide in binding to cytochrome oxidase, and also enhances sulfide detoxification by oxidizing sulfide to sulfate and thiosulfate., ${ }^{9,18}$ This suggests a role for hyperbaric oxygen therapy in hydrogen sulfide exposures, although it is not clear whether hyperbaric oxygen enhances the dissociation of the hydrogen sulfide-cytochrome aa3 complex. ${ }^{16-19}$ In addition to the potentially beneficial effects described above, hyperbaric oxygen therapy triggers peripheral vasoconstriction, reduces cerebral edema, increases tissue oxygen tension, decreases leukocyte adhesion (thus inhibiting inflammatory responses), enhances nerve cell regeneration, and decreases lipid peroxidation. ${ }^{20-22}$ In severe cases, it is probably best to administer hyperbaric oxygen therapy as early as possible. Hyperbaric oxygen also has reported toxicity, including barotrauma, oxygen toxicity and the risks of transferring an unstable patient to a remote hyperbaric facility.

The hyperbaric treatment protocols applied in these cases were based on a previous hydrogen sulfide case report $^{9}$ and on the Weaver protocol for carbon monoxide intoxication, ${ }^{23}$ although $\mathrm{CO}$ and $\mathrm{H}_{2} \mathrm{~S}$ have different mechanisms of toxicity. Case reports describing HBO therapy for hydrogen sulfide poisoning are scarce, ${ }^{24-28}$ and all but one ${ }^{29}$ favour this modality when initiated early. There are no human clinical trial data available, and it is unlikely that that clinical trials will be conducted in the future. However, in rat models of sulfide poisoning, 3 atmosphere absolute (ATA) oxygen therapy and sodium nitrite administration were associated with lower mortality than $100 \%$ oxygen at 1ATAor sodium nitrite alone. ${ }^{30}$

\section{Conclusion}

These cases suggest that hyperbaric oxygen therapy is safe when applied early in patients with severe hydrogen sulfide exposure. It is impossible to know whether our patients' favourable outcomes were the result of HBO treatment; however, based on these cases and previous data, we believe that, in addition to supportive care and nitrite administration, hyperbaric oxygen therapy, if available, may be considered as early as possible in cases of moderate to severe hydrogen sulfide poisoning.

Competing interests: None declared.

\section{References}

1. Reiffenstein RJ, Hulbert WC, Roth SH. Toxicology of hydrogen sulfide. Annu Rev Pharmacol Toxicol 1992;3:109-34.

2. Burnett WW, King EG, Grace M, Hall WF. Hydrogen sulphide 
poisoning: review of a 5 years experience. CMAJ 1977;117(3): 1277-80.

3. Tvedt B, Skyberg K, Aaserud O, Hobbesland A, Mathiesen T. Brain damage caused by hydrogen sulfide: a follow up study of six patients. Am J Ind Med 1991;20:91-101.

4. Tvedt B, Edland A, Skyberg K, Forberg O. Delayed neuropsychiatric sequelae after acute hydrogen sulfide poisoning: affection of motor function, memory, vision and hearing [published erratum appears in Acta Neurol Scand 1992;85(5):376]. Acta Neurol Scand 1991;84(4):348-51.

5. Legris M, Tanguay F, Labrecque R. Rapport d'expertise produit pour la CSST Chaudière Appalaches sur l'échantillonnage de gaz de fermentation lors d'une simulation des conditions environnementales de l'accident survenu le 19 mai 2004 à l'entreprise Camionnage Fernand Marcoux. 2004 sept.

6. Cadet F, Roy C. Rapport d'enquête de la Commision de Santé et Sécurité au Travail (CSST) sur l'accident de travail survenu à un employeur, un travailleur et à 3 sauveteus le 19 mai 2004 à l'entreprise Camionnage Fernand Marcous Inc. 2005 fév. Dossier d'intervention DP14040699, No rapport RAP0254910.

7. Donham KJ, Knapp LW, Monson R, Gustafson K. Acute exposure to gases from liquid manure. J Occup Med 1982;2:142-5.

8. U.S Environmental Protection Agency. Toxicological review of hydrogen sulfide (CAS no. 7783-06-4): in support of summary information on the integrated risk. Available at: http://30.epa .gov/iris/subst/0061.htm (accessed 2005 June 8).

9. Gunn B, Wong R. Noxious gas exposure in the outback: Two cases of hydrogen sulfide toxicity [review]. Emerg Med (Fremantle) 2001;13(2):240-6.

10. Kage S, Kashimura S, Ikeda H, Kudo K, Ikeda N. Fatal and nonfatal poisoning by hydrogen sulfide at an industrial waste site. J Forensic Sci 2002;47(3):652-5.

11. Green FH, Scheurch S, De Sanctis GT, Wallace JA, Cheng S, Prior M. Effects of hydrogen sulphide exposure on surface properties of lung surfactant. J Appl Physiol 1991;70(5):1943-9.

12. Rogers RE, Ferrin J. Effect of hydrogen sulphide on bacterial inactivation in the rat lung. Arch Environ Health 1981;36(5):261-4.

13. Gregorakos L, Dimopoulos G, Liberi S, Antipas G. Hydrogen sulfide poisoning: management and complications. Angiology 1995;46(12):1123-31

14. Hall AH, Rumack BH. Hydrogen sulfide poisoning: an antidotal role for sodium nitrite? Vet Hum Toxicol 1997;39(3):152-4.

15. Smith RP, Kruszyna R, Kruszyna H. Management of acute sulfide poisoning. Effects of oxygen, thiosulfate, and nitrite. Arch Environ Health 1976;31(3):166-9.

16. Smith RP. Sulfide poisoning. J Toxicol Clin Toxicol 1997; 35(3):305-6.

17. Smith RP, Gosselin RE. Hydrogen sulphide poisoning. J Occup
Med 1979;21(2):93-7.

18. Smilkstein MJ, Bronstein AC, Pickett HM, Rumack BH. Hyperbaric oxygen therapy for severe hydrogen sulfide poisoning. J Emerg Med 1985;3(1):27-30.

20. Thom SR. Effect of hyperoxia on neutrophil adhesion. Undersea Hyperb Med 2004;31(1):123-31.

21. Kindwall EP. The physiologic effects of hyperbaric oxygenation. In: Kindwall EP, Whelan HT, editors. Hyperbaric medicine practice, rev ed. Flagstaff (AZ): Best Publishing Company; 2002. p. 21-36.

22. Tomaszewski CA, Thom SR. Use of hyperbaric oxygen in toxicology. Emerg Med Clin North Am 1994;12(2):437-59.

19. Takano T,Miyazaki Y, Nashimoto I, Kobayashi K. Effect of hyperbaric oxygen on cyanide intoxication: in situ changes in intracellular oxidation reduction. Undersea Biomed Res 1980;7(3):191-7.

23. Weaver LK, Hopkins RO, Chan KJ, Churchill S, Elliott CG, Clemmer TP, et al. Hyperbaric oxygen for acute monoxide poisoning. N Engl J Med. 2002;347(14):1057-67.

24. Whitcraft DD 3rd, Bailey TD, Hart GB. Hydrogen sulfide poisoning treated with hyperbaric oxygen. J Emerg Med 1985;3(1):23-5.

25. Pontani BA, Warriner RA, Newman RK. Delayed neurologic sequelae after hydrogen sulfide poisoning treated with hyperbaric oxygen therapy: a case report. Proceeding of the Undersea and Hyperbaric Medical Society Annual Scientific Meeting; 1998 May 19-26 Seattle, USA. Undersea Hyperb Med 1998;25:S10.

26. Goldenberg I, Shoshani O, Mushkat Y Bentur Y, Melamed Y, Shupak A. [Hyperbaric oxygen for hydrogen sulfide poisoning.] Harefuah 1994;127(9):300-2, 360

27. Smilkstein MJ, Bronstein AC, Pickett HM, Rumack BH. Hyperbaric oxygen therapy for severe hydrogen sulfide poisoning. J Emerg Med 1985;3(1):27-30.

28. Hsu P, Li HW, Lin YT. Acute hydrogen sulfide poisoning treated with hyperbaric oxygen. J Hyperbaric Med 1987; 2(4):215-21.

29. Al-Mahasneh QM, Cohle SD, Haas E. Lack of response to hyperbaric oxygen in a fatal case of hydrogen sulfide poisoning: a case report. Vet Hum Toxicol 1989;31(4):353.

30. Bitterman N, Talmi Y,Lerman A, Melamed Y, Melamed Y, Taitelman U. The effect of hyperbaric oxygen on acute experimental sulfide poisoning in the rat. Toxic Appl Pharmacol $1986 ; 84: 325-8$

Correspondence to: Dr. Richard Belley, Emergency Department and Hyperbaric Facility, Centre Hospitalier Affilié de l'Hôtel Dieu de Lévis, 143 rue Wolfe, Lévis QC G6V3Z1 